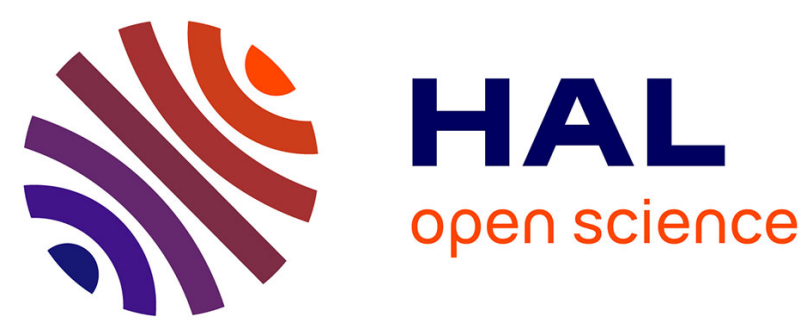

\title{
Preparation of chiral ruthenium(IV) complexes and applications in regio- and enantioselective allylation of phenols.
}

Zeyneb Sahli, Nolwenn Derrien, Simon Pascal, Bernard Demerseman, Thierry

Roisnel, Frédéric Barrière, Mathieu Achard, Christian Bruneau

\section{To cite this version:}

Zeyneb Sahli, Nolwenn Derrien, Simon Pascal, Bernard Demerseman, Thierry Roisnel, et al.. Preparation of chiral ruthenium(IV) complexes and applications in regio- and enantioselective allylation of phenols.. Dalton Transactions, 2011, 40 (20), pp.5625-30. 10.1039/c0dt01812k . hal-00615277

\section{HAL Id: hal-00615277 \\ https://hal.science/hal-00615277}

Submitted on 15 Jul 2013

HAL is a multi-disciplinary open access archive for the deposit and dissemination of scientific research documents, whether they are published or not. The documents may come from teaching and research institutions in France or abroad, or from public or private research centers.
L'archive ouverte pluridisciplinaire HAL, est destinée au dépôt et à la diffusion de documents scientifiques de niveau recherche, publiés ou non, émanant des établissements d'enseignement et de recherche français ou étrangers, des laboratoires publics ou privés. 


\title{
Transactions
}

Cite this: Dalton Trans., 2011, 40, 5625

\section{Preparation of chiral ruthenium(IV) complexes and applications in regio- and enantioselective allylation of phenols $\uparrow$}

\author{
Zeyneb Sahli, Nolwenn Derrien, Simon Pascal, Bernard Demerseman, Thierry Roisnel, Frédéric Barrière, \\ Mathieu Achard and Christian Bruneau*
}

Received 22nd December 2010, Accepted 1st April 2011

DOI: $10.1039 / \mathrm{codt01812k}$

Facile preparations of chiral $\left[\mathrm{Ru}\left(\mathrm{Cp}^{*}\right)\right]$ - and $\left[\mathrm{Ru}\left(\mathrm{Cp}^{\prime}\right)\right]$-based allyl complexes featuring N,O chelate derived from (+)-nopinone are described. Single crystal X-ray structural analysis of one complex revealed the preferential configuration of the ruthenium centre and the orientation of the unsymmetrical allylic substituent. Applications of these complexes in catalysis for nucleophilic allylic substitution allowed regio- and enantioselective formation of branched allyl ethers from phenols.

\section{Introduction}

Allylation reactions catalyzed by transition-metal complexes have attracted much interest as a powerful tool in organic synthesis for $\mathrm{C}-\mathrm{C}$ and $\mathrm{C}$-heteroatom bond formation. ${ }^{1}$ Among them, allylation of phenols and alcohols has retained lot of interest due to their potential applications in syntheses for the access of bioactive compounds and polymers. ${ }^{2}$ In the last decade, ruthenium precatalysts have been used in these reactions with unsymmetrical allylic substrates to promote regio- and enantioselective formation of branched compounds containing a chiral centre. ${ }^{3}$ Since the seminal work of asymmetric alkylation and amination catalyzed by ruthenium complexes starting from symmetrical substrates by Takahashi, ${ }^{4}$ we reported the first ruthenium-catalyzed enantioselective etherification starting from unsymmetrical allylic chlorides using a catalytic system based on $\left[\mathrm{Ru}\left(\mathrm{Cp}^{*}\right)\left(\mathrm{CH}_{3} \mathrm{CN}\right)_{3}\right]\left[\mathrm{PF}_{6}\right] \mathbf{I}$ along with chiral bisoxazolines reaching $82 \%$ ee but with moderate regioselectivities. ${ }^{5}$ In a similar manner, enantioselective Caroll rearrangement ${ }^{6}$ or decarboxylative etherification from allyl aryl carbonate $^{7}$ in the presence of iminopyridines and pyridineoxazolines afforded good regioselectivities and ee up to $87 \%$. Cyclopentadienyl ruthenium centres coordinated by chiral diamines have also been investigated in allylation reaction. The best regioselectivity (94\%) and enantioselectivity (54\%) were obtained during the substitution of cinnamyl chloride by phenol. ${ }^{8}$ More recently, planar-chiral cyclopentadienyl ruthenium catalysts have led to a breakthrough allowing excellent regio- and enantioselectivities in etherification and other allylation reactions starting from allylic chlorides. ${ }^{9}$ Ruthenium complexes featuring N,O and $\mathrm{P}, \mathrm{O}$ chelate have demonstrated good activities in allylation

UMR6226 CNRS - Université de Rennes, Sciences chimiques de Rennes, Catalyse et Organométalliques, Campus de Beaulieu, 35042, Rennes Cedex, France. E-mail: christian.bruneau@univ-rennes1.fr; Fax: +33 223236939; Tel: +33223236283

$\dagger$ CCDC reference number 793151. For crystallographic data in CIF or other electronic format see DOI: $10.1039 / \mathrm{c} 0 \mathrm{dt} 01812 \mathrm{k}$ reactions, ${ }^{10,11}$ and recently, Kitamura has shown the high efficiency of chiral naphthyl pyridine carboxylic acids with atropochirality acting as N,O chelates associated to $\left[\mathrm{Ru}(\mathrm{Cp})\left(\mathrm{CH}_{3} \mathrm{CN}\right)_{3}\right]\left[\mathrm{PF}_{6}\right]$ for the enantioselective dehydrative cyclisation of $\omega$-hydroxy allyl alcohols. ${ }^{12}$ However, such N,O chelates require preparative chiral HPLC for ligand purification and to date no N,O chelates derived from the chiral pool have been applied in rutheniumcatalyzed enantioselective etherification. Moreover, no structure of chiral complexes was reported to determine the preferential configuration of the ruthenium centre. We report herein the straighforward synthesis of chiral allyl ruthenium(IV) complexes containing an optically pure N,O chelate along with various substituted cyclopentadienyl ligands, and their applications in enantioselective allylation starting from cinnamyl carbonate.

\section{Results and discussion}

The ester 2 was synthesized in $45 \%$ overall yield from (+)-nopinone using a reported methodology ${ }^{13}$ involving Michael addition, imine formation and ring closure followed by triflation and methoxycarbonylation. Its hydrolysis in the presence of lithium hydroxide afforded the expected pyridine carboxylic acid 3 in $95 \%$ yield (Scheme 1).

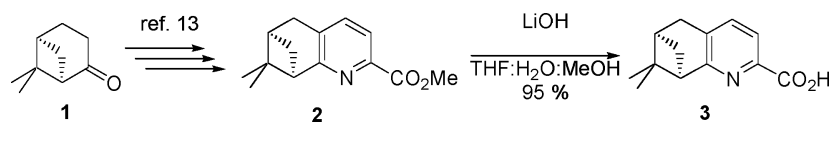

Scheme 1 Ligand preparation.

With this ligand in hand, we undertook the preparation of allyl ruthenium(IV) complexes. Thus, reaction of the ligand $\mathbf{3}$ in the presence of complex I followed by the addition of allyl alcohol resulted in substitution of the labile acetonitrile ligands and to the generation of water to yield the expected allyl ruthenium(IV) complex II as a diastereoisomeric mixture in a $75 / 25$ ratio and almost quantitative yield (Scheme 2). ${ }^{11 a}$ 

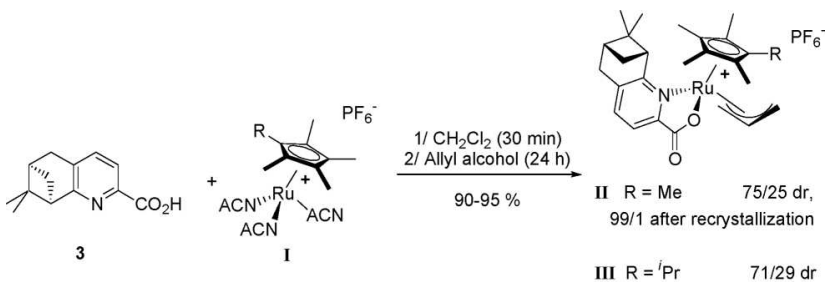

IV $\mathrm{R}=\mathrm{CH}_{2} \mathrm{CMe}_{3} 66 / 34 \mathrm{dr}$

V $R={ }^{t} \mathrm{Bu}$

Scheme 2 Complexes synthesis.

The ${ }^{1} \mathrm{H}$ NMR data of the fully characterized air stable complex II gives two singlets at $0.8 \mathrm{ppm}$ and $0.7 \mathrm{ppm}$ that allow facile determination of the major and minor diastereoisomer, respectively. ${ }^{1} \mathrm{H}$ NMR analyses show evidence of a constant stereoisomeric mixture but importantly, as indicated by disappearance of the minor singlet, recrystallization of II by layering dichloromethane and hexane in the presence of a small amount of methanol allowed the formation of pure crystals of the major isomer in $51 \%$ yield and a major/minor ratio superior to $99 / 1$. In a similar manner, reactions of $\left[\mathrm{Ru}\left(\mathrm{Cp}^{\prime}\right)\left(\mathrm{CH}_{3} \mathrm{CN}\right)_{3}\right]\left[\mathrm{PF}_{6}\right]$ where $\mathrm{Cp}^{\prime}$ contains isopropyl, neopentyl or tertiobutyl groups led to the formation of the expected complexes III, IV and $\mathbf{V}$, respectively, also as a stereoisomeric mixture (Scheme 2). ${ }^{14}$ Unfortunately, attempts to isolate the major isomer of these complexes were unsuccessful. Comparing the influence of the substituent on the cyclopentadienyl ligand, ${ }^{1} \mathrm{H}$ NMR of complexes II-V revealed that the steric hindrance of the substituent led to decrease of the diastereoisomers ratio. Thus, the lowest ratio was obtained with complex $\mathbf{V}$ featuring the highly sterically demanding ${ }^{t} \mathrm{Bu}$ moiety. Interestingly, with the use of the unsymmetrical crotyl alcohol, the reaction of complex I afforded the enantiopure complex VI as sole stereoisomer after recrystallization, which was confirmed by ${ }^{1} \mathrm{H}$ NMR with the disappearance of the singlet at $0.7 \mathrm{ppm}$ corresponding to the minor stereoisomer (Scheme 3). The structure of VI was unequivocally elucidated by single crystal X-ray diffraction study (Fig. 1 and Table 1). Complex VI presents a square- pyramidal structure, with the nitrogen and oxygen atoms from the ligand $\mathbf{3}$ and the terminal carbons of the $\eta^{3}$-allyl ligand at the basal positions. ${ }^{15} \mathrm{As}$ expected, the ligand is acting as a $\mathrm{N}, \mathrm{O}$ chelate with the formation of the five membered metallacycle. The chelate angle N(18)-Ru(1)$\mathrm{O}(15)$ is $77.87^{\circ}$ and is consistent with similar previously described complexes. ${ }^{10 a, 11 a}$ As already reported for allyl ruthenium complexes featuring hindered $\mathrm{Cp}^{*}$ ligand, the orientation of the allyl ligand is endo relative to the $\mathrm{Cp}^{*}{ }^{10 a, 15,16,17}$ More interestingly, only the complex containing the carboxylate moiety in cis relationship toward the methyl substituent of the allyl moiety is observed. ${ }^{10 a, 11 a, c}$ Comparing ruthenium-carbon bonds, the unsubstituted terminal allylic carbon atom is closer to the ruthenium centre than the substituted one with bonds of 2.199(4) and 2.302(4) $\AA$, respectively. Gas phase DFT geometry optimization of the cation in VI and of its diastereoisomer (Gaussian03 B3LYP/LanLD2Z) yields a

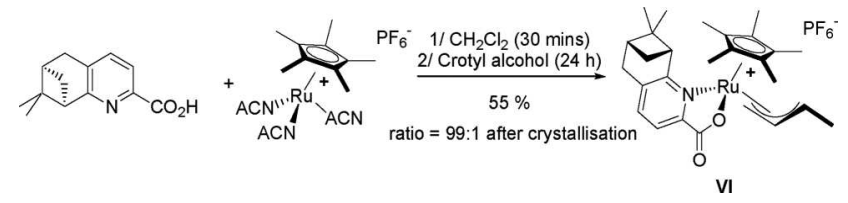

Scheme 3 Ruthenium complex VI from crotyl alcohol.
Table 1 Selected bond lengths $(\AA)$, angles $\left({ }^{\circ}\right)$, atom distances and summary of crystallographic parameters and refinement results for complex $\mathbf{V I}^{a}$

\begin{tabular}{|c|c|c|c|}
\hline Formula & $\begin{array}{l}\mathrm{C}_{54} \mathrm{H}_{72} \mathrm{~F}_{12} \mathrm{~N}_{2} \mathrm{O}_{4}- \\
\mathrm{P}_{2} \mathrm{Ru}_{2}\end{array}$ & $\mathrm{Ru}(1)-\mathrm{C}(11)$ & $2.199(4)$ \\
\hline F.W. & 1305.22 & $\mathrm{Ru}(1)-\mathrm{C}(12)$ & $2.173(4)$ \\
\hline Cryst. Syst. & Monoclinic & $\mathrm{Ru}(1)-\mathrm{C}(13)$ & $2.302(4)$ \\
\hline Space group & $C 2 y$ & $\mathrm{Ru}(1)-\mathrm{N}(18)$ & $2.165(3)$ \\
\hline$a / \AA ̊$ & $35.2478(14)$ & $\mathrm{Ru}(1)-\mathrm{O}(15)$ & $2.068(3)$ \\
\hline$b / \AA$ & $8.9626(4)$ & $\mathrm{C}(16)-\mathrm{O}(17)$ & $1.239(6)$ \\
\hline$c / \AA$ & $24.9400(10)$ & $\mathrm{C}(27)-\mathrm{N}(18)$ & $1.361(6)$ \\
\hline$\alpha /^{\circ}$ & 90 & $\mathrm{C}(13)-\mathrm{C}(14)$ & $1.507(8)$ \\
\hline$\beta /^{\circ}$ & $134.2050(10)$ & $\mathrm{O}(15)-\mathrm{C}(16)$ & $1.280(6)$ \\
\hline$\gamma /{ }^{\circ}$ & 90 & $C(16)-C(19)$ & $1.495(6)$ \\
\hline$V / \AA^{3}$ & $5647.9(4)$ & $\mathrm{N}(18)-\mathrm{C}(19)$ & $1.379(6)$ \\
\hline$Z$ & 4 & $\mathrm{C}(26)-\mathrm{C}(6)$ & 3.273 \\
\hline$d_{\text {calc }} / \mathrm{g} \mathrm{cm}^{-3}$ & 1.535 & $\mathrm{C}(25)-\mathrm{C}(6)$ & 3.433 \\
\hline$\mu / \mathrm{mm}^{-1}$ & 0.677 & $\mathrm{~N}(18)-\mathrm{Ru}(1)-\mathrm{O}(15)$ & $77.87(13)$ \\
\hline$F(000)$ & 2672 & $\mathrm{C}(16)-\mathrm{O}(15)-\mathrm{Ru}(1)$ & $118.6(3)$ \\
\hline no. of reflns collected & 42236 & $\mathrm{O}(17)-\mathrm{C}(16)-\mathrm{O}(15)$ & 124.1(4) \\
\hline no. of unique reflns & 12429 & $\mathrm{C}(11)-\mathrm{Ru}(1)-\mathrm{N}(18)$ & $87.38(16)$ \\
\hline$R_{\text {int }}$ & 0.0427 & $\mathrm{C}(11)-\mathrm{Ru}(1)-\mathrm{C}(12)$ & $37.81(18)$ \\
\hline Parameters & 692 & $\mathrm{C}(12)-\mathrm{Ru}(1)-\mathrm{C}(13)$ & $36.14(18)$ \\
\hline$T / \mathrm{K}$ & $100(2)$ & $\mathrm{N}(18)-\mathrm{C}(27)-\mathrm{C}(26)$ & $122.3(4)$ \\
\hline GOF & 1.04 & $\mathrm{C}(26)-\mathrm{C}(25)-\mathrm{C}(24)$ & $85.7(4)$ \\
\hline$R_{1}$ (all data) & 0.0455 & $\mathrm{C}(26)-\mathrm{C}(28)-\mathrm{C}(24)$ & $84.8(3)$ \\
\hline $\mathrm{w} R_{2}$ (all data $)^{b}$ & 0.1091 & $\mathrm{C}(30)-\mathrm{C}(28)-\mathrm{C}(29)$ & $110.2(5)$ \\
\hline$\Delta \rho \max / \mathrm{e} \AA^{-3}$ & 1.209 & $\mathrm{C}(27)-\mathrm{C}(26)-\mathrm{C}(25)$ & 107.4(3) \\
\hline$\Delta \rho \min / \mathrm{e} \AA^{-3}$ & -0.755 & $\mathrm{C}(23)-\mathrm{C}(24)-\mathrm{C}(25)$ & $107.8(4)$ \\
\hline
\end{tabular}

${ }^{a}$ Mo-K $\alpha$ radiation $(\lambda=0.71073 \AA) .{ }^{b} w=1 /\left[\sigma^{2}\left(F_{\mathrm{o}}\right)^{2}\right)+(0.0503 P)^{2}+$ $20.9699 P]$ where $P=\left(F_{\mathrm{o}}{ }^{2}+2 F_{\mathrm{c}}{ }^{2}\right) / 3$.

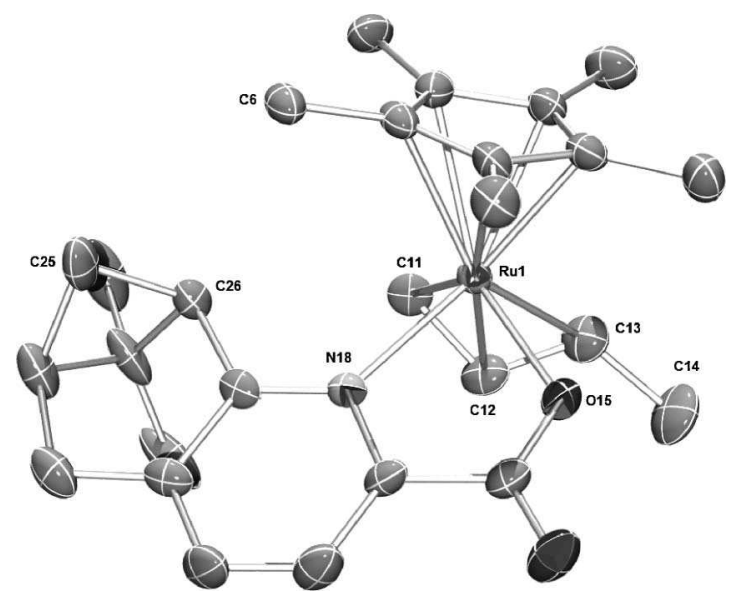

Fig. 1 Structure of enantiomerically pure complex VI. Thermal ellipsoids are drawn at the $50 \%$ probability level. Hydrogen atoms, $\mathrm{PF}_{6}$ counter anion are omitted for clarity.

stabilization of the major complex VI of $1.1 \mathrm{kcal} \mathrm{mol}^{-1}$ (Fig. 2). In addition, theoretical investigation of the carboxylic/crotyl alcohol intermediates shows optimized isoelectronic structures displaying a hydrogen bond between the proton of the coordinated carboxylic acid and the oxygen atom of the $\eta^{2}$-coordinated crotyl alcohol (Fig. 3).$^{18}$ Calculations on the earlier carboxylic/acetonitrile intermediates yield a stabilization of $1.5 \mathrm{kcal} \mathrm{mol}^{-1}$ of the "pro-VI" diastereoisomer. Taken together, these calculations indicate that the synthesis yielding the major diastereoisomer of VI is probably driven early in the synthetic sequence, and that the hydrogenbonded complex is a valid intermediate before dehydration. ${ }^{18}$ 


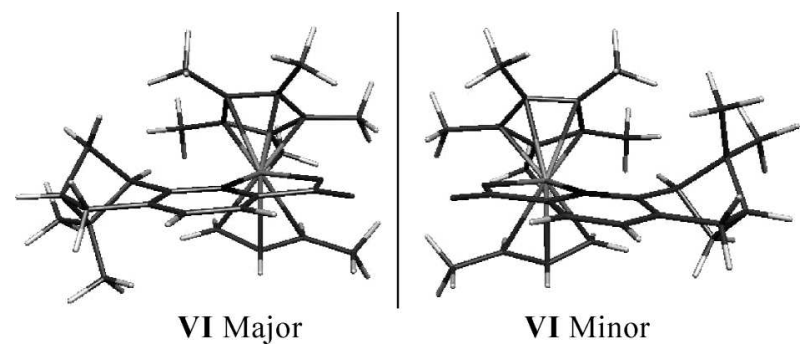

Fig. 2 Optimized diastereoisomer complexes VI.

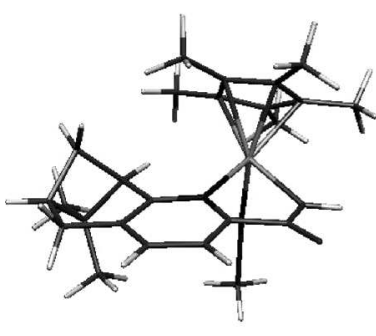

$\left[\mathrm{RuCp} *(\mathbf{3})\left(\mathrm{CH}_{3} \mathrm{CN}\right)\right]^{+}$

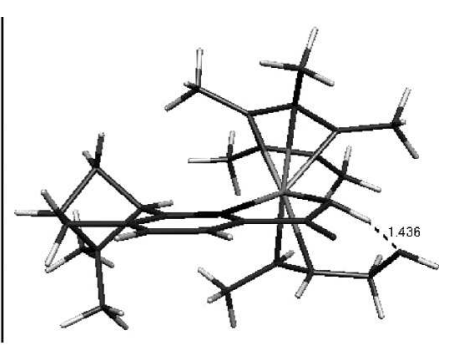

$\left[\mathrm{RuCp} *(3)\left(\mathrm{MeCH}=\mathrm{CHCH}_{2} \mathrm{OH}\right)\right]^{+}$
Fig. 3 Depiction of computed transient intermediates for complex VI.

Complexes II-VI were evaluated for their activities in regioand enantioselective allylation, using cinnamyl carbonate as linear substrate in the presence of phenol acting as nucleophile and potassium carbonate as mineral base (Table 2). Complexes IIVI were efficient in acetone or halogenated solvent such as dichloromethane or 1,2-dichloroethane, and gave conversions located in the range $64-89 \%$ in THF (entries 5-9). Notably, for all the solvents and complexes evaluated, excellent regioselectivities toward the branched compound 7 were obtained when potassium carbonate was used as base. In contrast, lower regioselectivities were obtained with the use of caesium carbonate using THF as solvent (not presented in the Table). However, although conversions and regioselectivities were satisfactory, enantioselectivities were found to be strongly solvent dependent. Thus, when the reactions were carried out in low polar halogenated solvent such as $\mathrm{CH}_{2} \mathrm{Cl}_{2}$ or $\mathrm{DCE}$, branched product 7 was formed with low levels of enantioselectivity of 29 and $8 \%$, respectively (entries 1 and 2). On the contrary, reactions in THF or acetone afforded promising enantioselectivities (entries 3-9). It is important to note that the best enantioselectivity was obtained with the less hindered pentamethylcyclopentadienyl ligand (entry 4, 5 and 9). Complexes II and VI differ only from the nature of the allylic ligand, which is removed during the first catalytic cycle and as a result, the same ee value of $76 \%$ was reached when complex II and VI were used as precatalyst (entries 4 and 9). Concerning the stereoisomeric purity of the precatalysts, entries 4 and 5 with complex II emphasized that the presence of the other stereoisomer is not prejudicial for the enantioselectivity and almost identical conversion, ratio and ee were obtained. This result might be explained by the formation of a transient intermediate during the catalytic cycle demonstrating a possible equilibrium between the two ruthenium(II) species leading after reaction with the allylic derivatives to the formation of both allylruthenium(Iv) stereoisomer intermediates (Fig. 4). ${ }^{18}$ We cannot also exclude an inner sphere mechanism during allylation reaction leading to the formation of unchelated species by exchange of the carboxylate
Table 2 Regio- and enantioselective allylation of phenol ${ }^{a}$

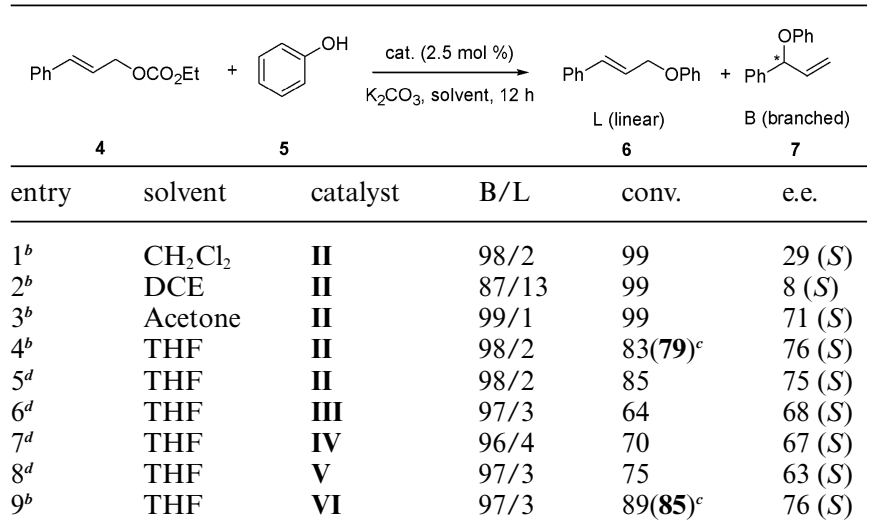

${ }^{a}$ Experimental conditions: all reactions were performed under an inert atmosphere of argon and carried out at $0.12 \mathrm{M}$ concentration with 4/5/base/precatalyst in 1/1.2/1.2/0.025 molar ratio at room temperature. ${ }^{b}$ entry $1-4: \mathbf{I I ~ d r}=99 / 1$, entry $9: \mathbf{V I ~ d r}=99 / 1 .{ }^{c}$ Isolated yield. ${ }^{d}$ reaction performed with precatalysts as a stereoisomeric mixture indicated in Scheme 2.

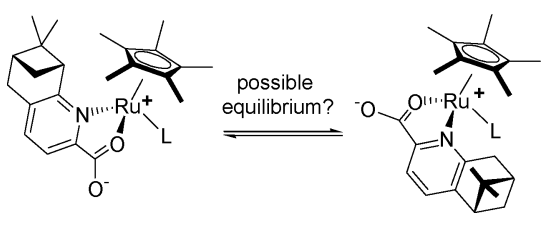

Fig. 4 Proposed equilibrium of the two ruthenium(II) intermediates.

moiety and the nucleophile. ${ }^{9 a, c}$ The absolute configuration of the major enantiomer of ether 7 determined by optical rotation measurement was $\mathrm{S}(+),{ }^{19}$ which tends to demonstrate that an inner sphere mechanism seems unprobable and thus supports the possible equilibrium of Fig. 4 prior to allylic activation and nucleophilic attack.

With regard to the use of other phenol derivatives such as $o$ cresol 8, reaction in the presence of pure precatalyst II proceeded smoothly allowing the exclusive formation of the branched allyl ether $\mathbf{1 0}$ in $85 \%$ isolated yield and $72 \%$ enantioselectivity (Scheme 4).

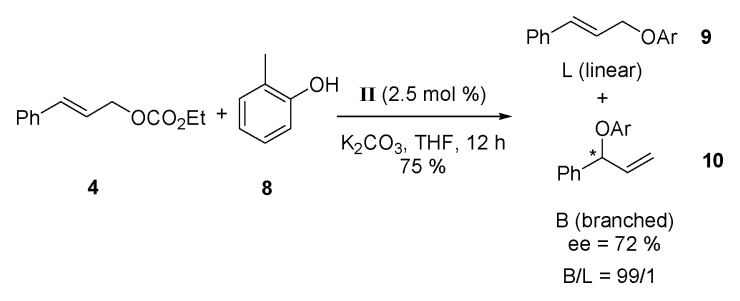

Scheme 4 Allylation with $o$-cresol.

The nature of the leaving group of the allylic derivative was then investigated. Thus, when the reaction was carried out in the presence of cinnamyl chloride 11 and phenol 5, branched product 7 was also formed preferentially but with poor enantioselectivity of $17 \%$ (Scheme 5). This result highlights the complementarity of the complexes featuring a chiral N,O chelate, which give better enantioselectivity from carbonate derivatives, with the reported chiral planar cyclopentadienyl ruthenium complexes ${ }^{9}$ or ruthenium complexes featuring bis-oxazoline ligand, ${ }^{5}$ which afforded 


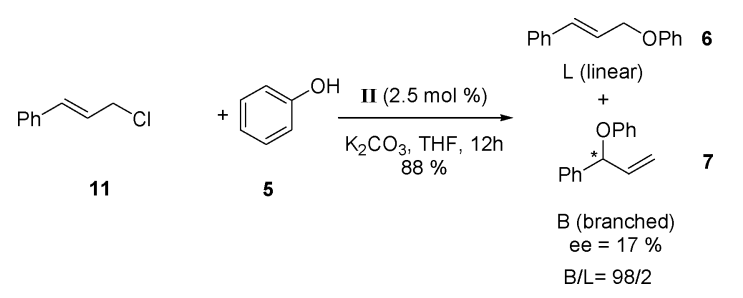

Scheme 5 Allylation with cinnamyl chloride.

better results with allylic chlorides and poor enantioselectivities with carbonates.

\section{Conclusions}

Chiral allyl ruthenium(IV) complexes featuring a N,O chelate derived from (+)-nopinone were easily prepared. As expected from our previous results with ruthenium catalysts featuring an achiral $\mathrm{N}, \mathrm{O}$ ligand derived from quinaldic acid, ${ }^{11 \mathrm{a}}$ the nucleophilic allylic substitution of cinnamyl carbonate by phenol, was highly regioselective in favour of branched chiral aryl allyl ethers. In addition, with the new ligand $\mathbf{3}$, both high regioselectivity and satisfactory enantioselectivity were obtained. Studies in enantioselective allylation reactions demonstrate the influence of the substituent on the cyclopentadienyl group for the enantioselectivity. The results also highlight the crucial importance of the leaving group of the allylic substrate for synthetic applications.

\section{Experimental section}

Unless otherwise stated, all manipulations were performed under inert atmosphere (argon) following conventional Schlenk techniques. Solvents were purified according to standard procedures. $\left[\mathrm{Ru}\left(\mathrm{Cp}^{*}\right)\left(\mathrm{CH}_{3} \mathrm{CN}\right)_{3}\right]\left[\mathrm{PF}_{6}\right]$ was prepared according to the literature method. ${ }^{11 \mathrm{a}}\left[\mathrm{Ru}\left(\mathrm{Cp}^{\prime}\right)\left(\mathrm{CH}_{3} \mathrm{CN}\right)_{3}\right]\left[\mathrm{PF}_{6}\right]$ complexes were prepared following reported protocols. ${ }^{14}$ Chiral ester 2 was synthesized according Kočovský methodology. ${ }^{13}$ All other reagents were obtained from the usual commercial suppliers, and used as received. NMR spectra were recorded in Bruker GPX (200 MHz) in $\mathrm{CDCl}_{3}$ or $\mathrm{CD}_{2} \mathrm{Cl}_{2}$, at room temperature unless otherwise stated. NMR spectra are referred to the internal residual solvent peak for ${ }^{1} \mathrm{H}$ and ${ }^{13} \mathrm{C}\{1 \mathrm{H}\}$ NMR.

\section{X-ray diffraction studies}

Suitable crystals were collected on a APEXII, Bruker-AXS diffractometer equipped with a CCD detector, using graphitemonochromated Mo-K $\alpha$ radiation $(\lambda=0.71073 \AA)$ at $T=$ $100(2) \mathrm{K}$. The structure was solved by direct methods using the SIR97 program, ${ }^{20}$ and then refined with full-matrix leastsquare methods based on $F^{2}$ (SHELX-97) with the aid of the WINGX ${ }^{21}$ program. The contribution of the disordered solvents to the calculated structure factors was estimated following the BYPASS algorithm, ${ }^{22}$ implemented as the SQUEEZE option in PLATON $^{23}$ A new data set, free of solvent contribution, was then used in the final refinement. All non-hydrogen atoms were refined with anisotropic atomic displacement parameters. $\mathrm{H}$ atoms were finally included in their calculated positions. A final refinement on $F^{2}$ with 12429 unique intensities and 692 parameters converged at $\omega R\left(F^{2}\right)=0.1076(R(F)=0.0427)$ for 11682 observed reflections with $I>2 \sigma(I)$. For parameters see Table 1 .

\section{Synthesis of compound 3}

A solution of ester 2 (389 mg, $1.68 \mathrm{mmol}, 1$ eq.) in THF-MeOH $(5: 1,6 \mathrm{~mL})$ was slowly added at $0{ }^{\circ} \mathrm{C}$ to a solution of lithium hydroxide (201.1 mg, $8.40 \mathrm{mmol}, 5$ eq.) in water $(2 \mathrm{~mL})$. After stirring the resulting mixture for one hour at $0{ }^{\circ} \mathrm{C}$, the solution was allowed to warm at room temperature and stirred for four hours. After complete conversion (TLC), the mixture was acidified to $\mathrm{pH}=2$ with $1 \mathrm{~N} \mathrm{HCl}$. After evaporation of THF, the remaining solution was extracted three times with dichloromethane. The combined organic layers were dried over sodium sulfate and concentrated to afford ligand $\mathbf{3}$ as a white powder in $92 \%$ yield (336 mg). ${ }^{1} \mathrm{H}$ NMR (200 MHz, $\left.\mathrm{CDCl}_{3}\right) \delta 8.02(\mathrm{~d}, J=7.3 \mathrm{~Hz}$, $1 \mathrm{H}), 7.66(\mathrm{~d}, J=7.5 \mathrm{~Hz}, 1 \mathrm{H}), 6.00$ (brs, $1 \mathrm{H}), 3.06-3.02(\mathrm{~m}, 3 \mathrm{H})$, 2.84-2.74 (m, 1H), 2.46-2.38 (m, 1H), $1.46(\mathrm{~s}, 3 \mathrm{H}), 1.29(\mathrm{~d}, J=$ $10.1 \mathrm{~Hz}, 1 \mathrm{H}), 0.66(\mathrm{~s}, 3 \mathrm{H}) ;{ }^{13} \mathrm{C} \mathrm{NMR}\left(50 \mathrm{MHz} \mathrm{CDCl}_{3}\right) \delta 166.6$, 165.3, 142.3, 137.5, 136.6, 122.2, 50.2, 40.2, 39.6, 31.9, 30.9, 26.3, $21.7 ;[\alpha]_{\mathrm{D}}^{20}=-24.6\left(\mathrm{c} 0.5, \mathrm{CH}_{2} \mathrm{Cl}_{2}\right)$.

\section{General procedure for the preparation of complexes II-VI}

A resulting violet solution containing $\left[\mathrm{Ru}\left(\mathrm{Cp}^{*}\right)\left(\mathrm{CH}_{3} \mathrm{CN}\right)_{3}\right]\left[\mathrm{PF}_{6}\right]$ or $\left[\mathrm{Ru}\left(\mathrm{Cp}^{\prime}\right)\left(\mathrm{CH}_{3} \mathrm{CN}\right)_{3}\right]\left[\mathrm{PF}_{6}\right](0.4 \mathrm{mmol})$ and ligand $3(0.4 \mathrm{mmol})$ in dichloromethane $(6 \mathrm{~mL})$ was stirred for thirty minutes at room temperature. Allyl alcohol or crotyl alcohol $(0.8 \mathrm{mmol})$ was then added and the solution turned immediately to yellow. After stirring overnight, the mixture was concentrated leaving a yellow solid, which was washed several times with degassed diethyl ether. The remaining powder was dried to afford complex as a stereoisomeric mixture. Further crystallization was possible with complexes II and VI by layering dichloromethane and hexane allowing the isolation of the major complex.

\section{$\left[\mathrm{Ru}\left(\mathrm{C}_{5} \mathrm{Me}_{5}\right)(\mathrm{N}-\mathrm{O})\left(\eta^{3}-\mathrm{CH}_{2} \mathrm{CHCH}_{2}\right)\right]\left[\mathrm{PF}_{6}\right]$ complex II}

Prepared from ligand 3 (100 mg, $0.46 \mathrm{mmol}, 1$ eq.), $\left[\mathrm{Ru}\left(\mathrm{Cp}^{*}\right)\left(\mathrm{CH}_{3} \mathrm{CN}\right)_{3}\right]\left[\mathrm{PF}_{6}\right](232 \mathrm{mg}, 0.46 \mathrm{mmol}, 1$ eq. $)$ and allyl alcohol $(78 \mu \mathrm{L}, 2$ eq.) to yield after recrystallization $66 \%(195 \mathrm{mg})$ of a yellow complex in a ratio superior to $99: 1 .{ }^{1} \mathrm{H}$ NMR $\left(200 \mathrm{MHz}, \mathrm{CD}_{2} \mathrm{Cl}_{2}\right): 7.96(\mathrm{~d}, J=7.8 \mathrm{~Hz}, 1 \mathrm{H}(=\mathrm{CH})), 7.93(\mathrm{~d}$, $J=7.8 \mathrm{~Hz}, 1 \mathrm{H}(=\mathrm{CH})), 4.76(\mathrm{~m}, 1 \mathrm{H}$ (allylic $\mathrm{CH})), 4.18(\mathrm{dd}$, $J=2.3,5.9 \mathrm{~Hz}, 1 \mathrm{H}($ syn allylic $\mathrm{CH})), 3,65(\mathrm{dd}, J=2.3,5.9 \mathrm{~Hz}$, $1 \mathrm{H}$ (syn allylic $\mathrm{CH})$ ), $3.36(\mathrm{~d}, J=10.3 \mathrm{~Hz}, 1 \mathrm{H}$ (anti allylic $\mathrm{CH})$ ), $3.16(\mathrm{~m}, 2 \mathrm{H}), 3.06-2.93(\mathrm{~m}, 1 \mathrm{H}), 2.69(\mathrm{~d}, J=10.5 \mathrm{~Hz}, 1 \mathrm{H}$ (anti allylic $\mathrm{CH})$ ), 2.59-2.47 (m, 2H), $1.72(\mathrm{~s}, 1 \mathrm{H}), 1.67\left(\mathrm{~s}, 15 \mathrm{H}\left(\mathrm{Cp}^{*}\right)\right)$, 1.55 (s, 3H (Me)), $1.29(\mathrm{~d}, J=10 \mathrm{~Hz}, 1 \mathrm{H}), 0.82(\mathrm{~s}, 3 \mathrm{H}(\mathrm{Me}))$; ${ }^{13} \mathrm{C}$ NMR $\left(50 \mathrm{MHz}, \mathrm{CD}_{2} \mathrm{Cl}_{2}\right): 171.9\left(\mathrm{CO}_{2}\right), 169.2\left(\mathrm{~N}=\mathrm{C}-\mathrm{CO}_{2}\right)$, $146.6(\mathrm{~N}=\mathrm{C}), 141.4(\mathrm{CH}=C), 140.1(\mathrm{C}=C), 127.5(\mathrm{CH}=C)$, $108.6\left(\mathrm{C}_{5} \mathrm{Me}_{5}\right), 100.8(\mathrm{CH}$ allyl $), 78.3\left(\mathrm{CH}_{2}\right.$ allyl $), 64.6\left(\mathrm{CH}_{2}\right.$ allyl $)$, $54.3(\mathrm{CH}), 39.5\left(\mathrm{CMe}_{2}\right), 39.5(\mathrm{CH}), 32.6\left(\mathrm{CH}_{2}\right), 32.2\left(\mathrm{CH}_{2}\right), 25.3$ (Me), $21.3(\mathrm{Me}), 9.7\left(C_{5} \mathrm{Me}_{5}\right)$; anal. calcd for $\mathrm{C}_{26} \mathrm{H}_{34} \mathrm{~F}_{6} \mathrm{NO}_{2} \mathrm{PRu}$ : C 48.90, H 5.37 found: C 48.79, H 5.41; HRMS calculated for $\mathrm{C}_{24} \mathrm{H}_{34} \mathrm{NO}_{2} \mathrm{Ru}^{+}:[\mathrm{M}]^{+}$494.16330, found $[\mathrm{M}]^{+}$494.1634; $[\alpha]_{\mathrm{D}}^{20}=+120$ (c $0.492, \mathrm{CH}_{2} \mathrm{Cl}_{2}$ ). 


\section{$\left[\mathrm{Ru}\left(\mathrm{C}_{5} \mathrm{Me}_{5}\right)(\mathrm{N}-\mathrm{O})\left(\eta^{3}-\mathrm{CH}_{2} \mathrm{CHCHMe}\right)\right]\left[\mathrm{PF}_{6}\right]$ complex VI}

Prepared from ligand 3 (90 mg, 0.41 mmol, 1 eq.), $\left[\mathrm{Ru}\left(\mathrm{Cp}^{*}\right)\left(\mathrm{CH}_{3} \mathrm{CN}\right)_{3}\right]\left[\mathrm{PF}_{6}\right](208 \mathrm{mg}, 0.41 \mathrm{mmol}, 1$ eq. $)$ and crotylalcohol $(70 \mu \mathrm{L})$ to yield after recrystallization $55 \%(148 \mathrm{mg})$ of a brown complex in a ratio superior to $99: 1 .{ }^{1} \mathrm{H}$ NMR $(200 \mathrm{MHz}$, $\left.\mathrm{CD}_{2} \mathrm{Cl}_{2}\right): 7.96(\mathrm{~d}, J=7.6 \mathrm{~Hz}, 1 \mathrm{H}(=\mathrm{CH})), 7.87(\mathrm{~d}, J=7.6 \mathrm{~Hz}$, $1 \mathrm{H}(=\mathrm{CH})), 4.46(\mathrm{dt}, J=10.3,6.2 \mathrm{~Hz}, 1 \mathrm{H}($ allylic $\mathrm{CH})), 4.12(\mathrm{dq}$, $J=10.3,6.2 \mathrm{~Hz}, 1 \mathrm{H}$ (allylic CHMe)), $3.58(\mathrm{dd}, J=0.6,6.2 \mathrm{~Hz}, 1 \mathrm{H}$ (syn allylic $\mathrm{CH})), 3.16(\mathrm{~m}, 2 \mathrm{H}), 2.96(\mathrm{td}, J=5.9,11.6 \mathrm{~Hz}, 1 \mathrm{H}), 2.61$ $(\mathrm{t}, J=5.4 \mathrm{~Hz}, 1 \mathrm{H}), 2.54-2.45(\mathrm{~m}, 2 \mathrm{H}), 1.63\left(\mathrm{~s}, 15 \mathrm{H}\left(\mathrm{Cp}^{*}\right)\right), 1.56(\mathrm{~s}$, $3 \mathrm{H}(\mathrm{Me})), 1.37(\mathrm{~d}, J=6.2 \mathrm{~Hz}, 3 \mathrm{H}(\mathrm{Me})), 1.27(\mathrm{~d}, J=10 \mathrm{~Hz}, 1 \mathrm{H})$, $0.81(\mathrm{~s}, 3 \mathrm{H}) ;{ }^{13} \mathrm{C} \mathrm{NMR}\left(50 \mathrm{MHz}, \mathrm{CD}_{2} \mathrm{Cl}_{2}\right): 171.8\left(\mathrm{CO}_{2}\right), 168.1$ $\left(\mathrm{N}-\mathrm{C}-\mathrm{CO}_{2}\right), 146.4(\mathrm{~N}=\mathrm{C}), 141.4(\mathrm{CH}=\mathrm{C}), 139.9(\mathrm{C}=\mathrm{C}), 126.3$ $(\mathrm{CH}=C), 107.5\left(C_{5} \mathrm{Me}_{5}\right), 101.3$ (CH allyl), 85.0 (CH-Me allyl), $62.3\left(\mathrm{CH}_{2}\right.$ allyl $), 54.5(\mathrm{CH}), 40.1(\mathrm{CMe}), 40.0(\mathrm{CH}), 32.5\left(\mathrm{CH}_{2}\right)$, $32.4\left(\mathrm{CH}_{2}\right), 25.3(\mathrm{Me}), 21.1(\mathrm{Me}), 17.3(\mathrm{Me}), 9.5\left(\mathrm{C}_{5} M e_{5}\right)$; anal. calcd for $\mathrm{C}_{27} \mathrm{H}_{36} \mathrm{~F}_{6} \mathrm{NO}_{2} \mathrm{PRu}: \mathrm{C} 49.69, \mathrm{H} 5.56$ found: $\mathrm{C} 49.59, \mathrm{H}$ 5.59; $[\alpha]_{\mathrm{D}}^{20}=+145\left(\mathrm{c} 0.5, \mathrm{CH}_{2} \mathrm{Cl}_{2}\right)$.

\section{$\left[\mathrm{Ru}\left(\mathrm{C}_{5} \mathrm{Me}_{4} i-\mathrm{Pr}\right)(\mathrm{N}-\mathrm{O})\left(\eta^{3}-\mathrm{CH}_{2} \mathrm{CHCH}_{2}\right)\right]\left[\mathrm{PF}_{6}\right]$ complex III}

Prepared from ligand 3 (30 mg, $0.14 \mathrm{mmol}, 1$ eq.), $\left[\mathrm{Ru}\left(\mathrm{C}_{5} \mathrm{Me}_{4} i_{\text {- }}\right.\right.$ $\left.\operatorname{Pr})\left(\mathrm{CH}_{3} \mathrm{CN}\right)_{3}\right]\left[\mathrm{PF}_{6}\right]$ (73 mg, $0.14 \mathrm{mmol}, 1$ eq.) and allyl alcohol $(18 \mu \mathrm{L})$ to yield after treatment $90 \%(82 \mathrm{mg})$ of a brown complex as a stereoisomeric mixture in a 72/29 ratio. Only the major isomer is described: ${ }^{1} \mathrm{H}$ NMR $\left(200 \mathrm{MHz}, \mathrm{CD}_{2} \mathrm{Cl}_{2}\right): 8.00(\mathrm{~d}, J=7.5 \mathrm{~Hz}$, $1 \mathrm{H}(=\mathrm{CH})), 7.9(\mathrm{~d}, J=7.5 \mathrm{~Hz}, 1 \mathrm{H}(=\mathrm{CH})), 4.62-4.79(\mathrm{~m}, 1 \mathrm{H}$ (allylic $\mathrm{CH})), 4.27(\mathrm{dd}, J=2.1,5.14 \mathrm{~Hz}, 1 \mathrm{H}($ syn allylic $\mathrm{CH})), 3.65$ (dd, $J=2.0,5.4 \mathrm{~Hz}, 1 \mathrm{H}($ syn allylic $\mathrm{CH})), 3.39$ (d, $J=10.6 \mathrm{~Hz}$, $1 \mathrm{H}$ (anti allylic $\mathrm{CH})), 3.17(\mathrm{~m}, 2 \mathrm{H}), 3.02-2.94(\mathrm{~m}, 1 \mathrm{H}), 2.75(\mathrm{~d}$, $J=10.7 \mathrm{~Hz}, 1 \mathrm{H}($ anti allylic $\mathrm{CH})), 2.66-2.49(\mathrm{~m}, 3 \mathrm{H}), 1.77(\mathrm{~s}, 3 \mathrm{H})$, 1.69 (s, 6H), 1.65 (s, 3H), $1.56(\mathrm{~s}, 3 \mathrm{H}), 1.29$ (d, $J=9.8 \mathrm{~Hz}, 1 \mathrm{H})$, $1.16\left(\mathrm{~d}, J=7 \mathrm{~Hz}, 6 \mathrm{H}, \mathrm{C}\left(\mathrm{CH}_{3}\right)_{2}\right), 0.82(\mathrm{~s}, 3 \mathrm{H}) ;{ }^{13} \mathrm{C} \mathrm{NMR}(75 \mathrm{MHz}$, $\left.\mathrm{CD}_{2} \mathrm{Cl}_{2}\right) \delta(\mathrm{ppm}): 171.7\left(\mathrm{CO}_{2}\right), 169.4\left(\mathrm{~N}=\mathrm{C}-\mathrm{CO}_{2}\right), 146.6(N=\mathrm{C})$, $141.4(\mathrm{CH}=C), 139.9(\mathrm{C}=C), 127.5(\mathrm{CH}=C), 118.0\left(\mathrm{Cp}^{\prime}\right), 112.8$ $\left(\mathrm{Cp}^{\prime}\right), 109.0\left(\mathrm{Cp}^{\prime}\right), 106.2\left(\mathrm{Cp}^{\prime}\right), 104.1\left(\mathrm{Cp}^{\prime}\right), 100.9$ (CH allyl), 78.2 $\left(\mathrm{CH}_{2}\right.$ allyl $), 64.5\left(\mathrm{CH}_{2}\right.$ allyl $), 52.4(\mathrm{CH}), 39.5\left(\mathrm{CMe}_{2}\right), 39.5(\mathrm{CH})$, $32.5\left(\mathrm{CH}_{2}\right), 32.0\left(\mathrm{CH}_{2}\right), 26.9\left(\mathrm{CHMe}_{2}\right), 25.3(\mathrm{Me}), 20.9(\mathrm{Me}), 20.2$ $\left(\mathrm{CHMe}_{2}\right) 15.4(\mathrm{CHMe}), 11.2(\mathrm{Me}), 10.0(\mathrm{Me}), 9.9(\mathrm{Me}), 9.8(\mathrm{Me})$. anal. calcd for $\mathrm{C}_{28} \mathrm{H}_{38} \mathrm{~F}_{6} \mathrm{NO}_{2} \mathrm{PRu}$ : C 50.45, H 5.75 found: $\mathrm{C} 50.36$, $\mathrm{H}$ 5.81; HRMS calculated for $\mathrm{C}_{28} \mathrm{H}_{38} \mathrm{NO}_{2} \mathrm{Ru}^{+}$: [M] ${ }^{+}$522.19405, found $[\mathrm{M}]^{+} 522.1948$.

\section{$\left[\mathrm{Ru}\left(\mathrm{C}_{5} \mathrm{Me}_{4} \mathrm{CH}_{2} \mathrm{CMe}_{3}\right)(\mathrm{N}-\mathrm{O})\left(\eta^{3}-\mathrm{CH}_{2} \mathrm{CHCH}_{2}\right)\right]\left[\mathrm{PF}_{6}\right]$ complex IV}

Prepared from ligand 3 (30 $\mathrm{mg}, 0.14$ mmol, 1 eq. $)$, $\left[\mathrm{Ru}\left(\mathrm{C}_{5} \mathrm{Me}_{4} \mathrm{CH}_{2} \mathrm{CMe}_{3}\right)\left(\mathrm{CH}_{3} \mathrm{CN}\right)_{3}\right]\left[\mathrm{PF}_{6}\right](78.5 \mathrm{mg}, 0.14 \mathrm{mmol}, 1$ eq. $)$ and allyl alcohol $(28 \mu \mathrm{L})$ to yield after treatment $88 \%(86 \mathrm{mg})$ of a brown complex as a stereoisomeric mixture in a 66/34 ratio. Only the major isomer is described: ${ }^{1} \mathrm{H}$ NMR $\left(200 \mathrm{MHz}, \mathrm{CD}_{2} \mathrm{Cl}_{2}\right)$ : $7.99(\mathrm{~d}, J=7.6 \mathrm{~Hz}, 1 \mathrm{H}(=\mathrm{CH})), 7.92(\mathrm{~d}, J=7.6 \mathrm{~Hz}, 1 \mathrm{H}(=\mathrm{CH}))$, 4.62-4.81 (m, 1H (allylic CH)), 4.24 (dd, $J=2.2,5.5 \mathrm{~Hz}, 1 \mathrm{H}($ syn allylic $\mathrm{CH})), 3.70(\mathrm{~d}, J=5.4 \mathrm{~Hz}, 1 \mathrm{H}($ syn allylic $\mathrm{CH})), 3.45(\mathrm{~d}$, $J=10.5 \mathrm{~Hz}, 1 \mathrm{H}$ (anti allylic $\mathrm{CH})$ ), 3.17 (brs, 2H), 2.94-3.08 (m, $1 \mathrm{H}), 2.73(\mathrm{~d}, J=11.0 \mathrm{~Hz}, 1 \mathrm{H}$ (anti allylic $\mathrm{CH})), 2.50-2.60(\mathrm{~m}$, 2H), 2.05 (d, $J=14 \mathrm{~Hz}, 1 \mathrm{H}), 1.78\left(\mathrm{~s}, 3 \mathrm{H}\left(\mathrm{Cp}^{\prime}\right)\right)$ 1.70(s, 3H $\left.\left(\mathrm{Cp}^{\prime}\right)\right)$, 1.64 (s, 3H ( $\left.\left.\mathrm{Cp}^{\prime}\right)\right), 1.63\left(\mathrm{~s}, 3 \mathrm{H}\left(\mathrm{Cp}^{\prime}\right)\right), 1.56\left(\mathrm{~s}, 3 \mathrm{H}\left(\mathrm{CMe}_{2}\right)\right), 1.30$ $(\mathrm{d}, J=10 \mathrm{~Hz}, 1 \mathrm{H}), 1.07\left(\mathrm{~s}, 9 \mathrm{H}\left(\mathrm{CMe}_{3}\right)\right), 0.80\left(\mathrm{~s}, 3 \mathrm{H}\left(\mathrm{CMe}_{2}\right)\right) ;{ }^{13} \mathrm{C}$ NMR (75 MHz, $\left.\mathrm{CD}_{2} \mathrm{Cl}_{2}\right): 171.8\left(\mathrm{CO}_{2}\right), 169.2\left(\mathrm{~N}=\mathrm{C}-\mathrm{CO}_{2}\right), 146.5$
$(\mathrm{N}=\mathrm{C}), 141.4(\mathrm{CH}=C), 140.1(\mathrm{C}=C), 127.6(\mathrm{CH}=C), 113.1$ $\left(\mathrm{Cp}^{\prime}\right), 111.6\left(\mathrm{Cp}^{\prime}\right), 110.5\left(\mathrm{Cp}^{\prime}\right), 106.7\left(\mathrm{Cp}^{\prime}\right), 104.8\left(\mathrm{Cp}^{\prime}\right), 101.2(\mathrm{CH}$ allyl), $79.5\left(\mathrm{CH}_{2}\right.$ allyl), $65.6\left(\mathrm{CH}_{2}\right.$ allyl $), 52.5(\mathrm{CH}), 39.4\left(\mathrm{CMe}_{2}\right)$, .39.4 (CH), $37.8\left(\mathrm{CH}_{2} \mathrm{CMe}_{3}\right), 35.7\left(\mathrm{CMe}_{3}\right), 32.6\left(\mathrm{CH}_{2}\right), 32.3\left(\mathrm{CH}_{2}\right)$, $30.6\left(\mathrm{CMe}_{3}\right), 25.3\left(\mathrm{CMe}_{2}\right), 21.2\left(\mathrm{CMe}_{2}\right), 11.7(\mathrm{Me}), 11.4(\mathrm{Me})$, $10.3(\mathrm{Me}), 10.05(\mathrm{Me})$; HRMS calculated for $\mathrm{C}_{30} \mathrm{H}_{42} \mathrm{NO}_{2} \mathrm{Ru}^{+}:[\mathrm{M}]^{+}$ 550.22590 , found $[\mathrm{M}]^{+} 550.2258$.

\section{$\left[\mathrm{Ru}\left(\mathrm{C}_{5} \mathrm{Me}_{4} t-\mathrm{Bu}\right)(\mathrm{N}-\mathrm{O})\left(\eta^{3}-\mathrm{CH}_{2} \mathrm{CHCH}_{2}\right)\right]\left[\mathrm{PF}_{6}\right]$ complex V}

Prepared from ligand 3 (30 mg, $0.14 \mathrm{mmol}, 1$ eq.), [ $\mathrm{Ru}\left(\mathrm{C}_{5} \mathrm{Me}_{4} t\right.$ $\left.\mathrm{Bu})\left(\mathrm{CH}_{3} \mathrm{CN}\right)_{3}\right]\left[\mathrm{PF}_{6}\right](75 \mathrm{mg}, 0.14 \mathrm{mmol}, 1 \mathrm{eq}$.) and allyl alcohol $(30 \mu \mathrm{L})$ to yield after treatment $89 \%(83 \mathrm{mg})$ of a brown complex as a stereoisomeric mixture in a 60/40 ratio. Only major isomer is described : ${ }^{1} \mathrm{H}$ NMR $\left(200 \mathrm{MHz}, \mathrm{CD}_{2} \mathrm{Cl}_{2}\right): 8.01(\mathrm{~d}, J=7.8 \mathrm{~Hz}$, $1 \mathrm{H}(=\mathrm{CH})), 7.94(\mathrm{~d}, J=7.7 \mathrm{~Hz}, 1 \mathrm{H}(=\mathrm{CH})), 4.73-4.56(\mathrm{~m}, 1 \mathrm{H}$ (allylic $\mathrm{CH})), 4.42(\mathrm{~d}, J=5.6 \mathrm{~Hz}, 1 \mathrm{H}($ syn allylic $\mathrm{CH})), 3.66(\mathrm{~d}$, $J=5.4 \mathrm{~Hz}, 1 \mathrm{H}($ syn allylic $\mathrm{CH})), 3.52(\mathrm{~d}, J=10 \mathrm{~Hz}$, (anti allylic CH)), 3.18 (brs, 2H), 3.07-2.94 (m, 1H), 2.70 (d, $J=10.5 \mathrm{~Hz}, 1 \mathrm{H}$ (anti allylic CH)), 2.52-2.46 (m, 2H), $1.87(\mathrm{~s}, 3 \mathrm{H}(\mathrm{Me})), 1.85(\mathrm{~s}, 3 \mathrm{H}$ (Me)), 1.72 (s, 3H (Me)), 1.64 (s, 3H, (Me)), 1.55 (s, 3H (Me)), 1.33 (brs, $9 \mathrm{H}\left(\mathrm{CMe}_{3}\right)$ ), 0.81(s, 3H (Me)); ${ }^{13} \mathrm{C} \mathrm{NMR}\left(75 \mathrm{MHz}, \mathrm{CD}_{2} \mathrm{Cl}_{2}\right)$ : $172.1\left(\mathrm{CO}_{2}\right), 169.2\left(\mathrm{~N}=\mathrm{C}-\mathrm{CO}_{2}\right), 146.6(\mathrm{~N}=\mathrm{C}), 141.4(\mathrm{CH}=C)$, $140.2(\mathrm{C}=C), 127,4(\mathrm{CH}=C), 119,8\left(\mathrm{Cp}^{\prime}\right), 117,7\left(\mathrm{Cp}^{\prime}\right), 110.6$ $\left(\mathrm{Cp}^{\prime}\right), 104.8\left(\mathrm{Cp}^{\prime}\right), 101.7\left(\mathrm{Cp}^{\prime}\right), 100.7$ ( $\mathrm{CH}$ allyl), $79.4\left(\mathrm{CH}_{2}\right.$ allyl), $65.3\left(\mathrm{CH}_{2}\right.$ allyl $), 53.4(\mathrm{CH}), 39.5\left(\mathrm{CMe}_{2}\right), 39.4(\mathrm{CH}), 36.4\left(\mathrm{CMe}_{3}\right)$, $32.6\left(\mathrm{CH}_{2}\right), 32.4\left(\mathrm{CH}_{2}\right), 30.5\left(\mathrm{CMe}_{3}\right), 25.3\left(\mathrm{CMe}_{2}\right), 21.2\left(\mathrm{CMe}_{2}\right)$, $13.8(\mathrm{Me}), 13.1(\mathrm{Me}), 11.1(\mathrm{Me}), 10.3(\mathrm{Me})$; HRMS calculated for $\mathrm{C}_{29} \mathrm{H}_{40} \mathrm{NO}_{2} \mathrm{Ru}^{+}:[\mathrm{M}]^{+}$536.21025, found [M] 536.2110 .

\section{General procedure for the allylation of phenols}

In a Schlenk tube containing cinnamyl carbonate $(50 \mathrm{mg}$, $0.24 \mathrm{mmol}, 1$ eq.), phenol (27 mg, $0.29 \mathrm{mmol}, 1.2$ eq.) in THF ( $2 \mathrm{~mL})$, potassium carbonate $(40 \mathrm{mg}, 0.29 \mathrm{mmol}, 1.2$ eq.) and precatalyst $(2.5 \mathrm{~mol} \%)$ were sequentially added. After stirring the solution at room temperature for $16 \mathrm{~h}$, the solution was filtered through a silica plug using diethyl ether as eluent. Conversions and $\mathrm{B} / \mathrm{L}$ ratio were determined by ${ }^{1} \mathrm{H}$ NMR. Enantioselectivities were determined by HPLC using chiralcel-OJ, H/I 99.5/0.5, $0.8 \mathrm{~mL} \mathrm{~min}-1, \lambda=220,250 \mathrm{~nm} ; t_{1}($ maj $)=29.1 \mathrm{~min}$. and $t_{2}(\mathrm{~min})=$ $32 \mathrm{~min}$.

\section{Acknowledgements}

The authors wish to thank Dr C. Guillaume and Dr S. Guillaume for the methoxycarbonylation reaction. Z. S. thanks the Ministry of Higher Education and Research of Algeria for PNE fellowship.

\section{Notes and references}

1 (a) J. Tsuji, Transition Metal Reagents and Catalysts: Innovations in Organic Synthesis, Wiley, Chichester, 2000, pp. 109; (b) G. Helmchen and A. Pfaltz, Acc. Chem. Res., 2000, 33, 336; (c) B. M. Trost and M. L. Crawley, Chem. Rev., 2003, 103, 2921; (d) Z. Lu and S. M. Ma, Angew. Chem., Int. Ed., 2008, 47, 258.

2 (a) B. M. Trost and F. D. Toste, J. Am. Chem. Soc., 1998, 120, 815; (b) B. M. Trost and F. D. Toste, J. Am. Chem. Soc., 1998, 120, 9074; (c) B. M. Trost and F. D. Toste, J. Am. Chem. Soc., 1999, 121, 4545; (d) P. A. Evans and D. K. Leahy, J. Am. Chem. Soc., 2000, 122, 5012; (e) B. M. Trost and F. D. Toste, J. Am. Chem. Soc., 2000, 122, 11262; (f) B. M. Trost, P. L. Fraisse and Z. T. Ball, Angew. Chem., Int. Ed., 
2002, 41, 1059; (g) P. A. Evans and D. K. Leahy, J. Am. Chem. Soc., 2002, 124, 7882; (h) B. M. Trost and W. Tang, J. Am. Chem. Soc., 2002, 124, 14542; (i) C. Welter, A. Dahnz, B. Brunner, S. Streiff, P. Dübon and G. Helmchen, Org. Lett., 2005, 7, 1239; (j) R. Hermatschweiler, I. Fernández, P. S. Pregosin and F. Breher, Organometallics, 2006, 25, 1440; $(k)$ Y. Uozumi and M. Kimura, Tetrahedron: Asymmetry, 2006, 17, 161; (l) S. F. Kirsch, L. E. Overman and N. S. White, Org. Lett., 2007, 9, 911; (m) S. Ueno and J. F. Hartwig, Angew. Chem., Int. Ed., 2008, 47, 1928; (n) J. A. van Rijn, E. van Stapele, E. Bouwman and E. Drent, J. Catal., 2010, 272, 220.

3 Reviews on ruthenium-catalyzed regio- and enantio-selective allylations: (a) T. Kondo and T. Mitsudo, Curr. Org. Chem. 2002, 6, 1163; (b) C. Bruneau, J.-L. Renaud and B. Demerseman, Chem.-Eur. J., 2006, 12, 5178; (c) J.-L. Renaud, B. Demerseman, M. D. Mbaye and C. Bruneau, Curr. Org. Chem., 2006, 10, 115.

4 (a) Y. Matsushima, K. Onitsuka, T. Kondo, T. Mitsudo and S. Takahashi, J. Am. Chem. Soc., 2001, 123, 10405; (b) K. Onitsuka, Y. Matsushima and S. Takahashi, Organometallics, 2005, 24, 6472.

5 M. D. Mbaye, J.-L. Renaude, B. Demerseman and C. Bruneau, Chem. Commun., 2004, 1870.

6 (a) S. Constant, S. Tortoioli, J. Muller and J. Lacour, Angew. Chem., Int. Ed., 2007, 46, 2082; (b) S. Constant, S. Tortoioli, J. Muller, D. Linder, F. Buron and J. Lacour, Angew. Chem., Int. Ed., 2007, 46, 8979; (c) M. Austeri, F. Buron, S. Constant, J. Lacour, D. Lindler, J. Müller and S. Tortioli, Pure Appl. Chem., 2008, 80, 967; (d) D. Lindler, M. Austeri and J. Lacour, Org. Biomol. Chem., 2009, 7, 4057.

7 M. Austeri, D. Lindler and J. Lacour, Chem.-Eur. J., 2008, 14, 5737.

8 M. Saporita, G. Bottari, G. Bruno, D. Drommi and F. Faraone, J. Mol. Catal. A: Chem., 2009, 309, 159.

9 (a) K. Onitsuka, H. Okuda and H. Sasai, Angew. Chem., Int. Ed., 2008, 47, 1454; (b) K. Onitsuka, C. Kameyama and H. Sasai, Chem. Lett., 2009, 38, 444; (c) N. Kanbayashi and K. Onitsuka, J. Am. Chem. Soc., 2010, 132, 1206.
10 (a) H. Saburi, S. Tanaka and M. Kitamura, Angew. Chem., Int. Ed., 2005, 44, 1730; (b) S. Tanaka, H. Saburi and M. Kitamura, Adv. Synth. Catal., 2006, 348, 375; (c) S. Tanaka, T. Seki and M. Kitamura, Angew. Chem., Int. Ed., 2009, 48, 8948.

11 (a) H.-J. Zhang, B. Demerseman, L. Toupet, Z. Xi and C. Bruneau, Adv. Synth. Catal., 2008, 350, 1601; (b) M. Achard, N. Derrien, H.J. Zhang, B. Demerseman and C. Bruneau, Org. Lett., 2009, 11, 185; (c) H.-J. Zhang, B. Demerseman, L. Toupet, Z. Xi and C. Bruneau, Organometallics, 2009, 28, 5173; (d) B. Sundararaju, M. Achard, B. Demerseman, L. Toupet, G. V. M. Sharma and C. Bruneau, Angew. Chem. Int. Ed., 2010, 49, 2782.

12 S. Tanaka, T. Seki and M. Kitamura, Angew. Chem., Int. Ed., 2009, 48, 8948.

13 (a) A. V. Malkov, D. Pernazza, M. Bell, M. Bella, A. Massa, F. Teplý, P. Meghani and P. Kočovský, J. Org. Chem., 2003, 68, 4727; (b) A. V. Malkov, A. J. P. Stewart-Liddon, F. Teplý, L. Kobr, K. W. Muir, D. Haigh and P. Kočovský, Tetrahedron, 2008, 64, 4011.

14 H.-J. Zhang, B. Demerseman, Z. Xi and C. Bruneau, Eur. J. Inorg. Chem., 2008, 3212.

15 H. Kondo, Y. Yamaguchi and H. Nagashima, Chem. Commun., 2000, 1075.

16 Y. Matsushima, K. Onitsuka and S. Takahashi, Organometallics, 2004, 23, 3763 .

17 B. Demerseman, J.-L. Renaud, L. Toupet, C. Hubert and C. Bruneau, Eur. J. Inorg. Chem., 2006, 1371.

18 For mechanistic consideration for similar kind of reaction see: M. K. Kiesewetter and R. M. Waymouth, Organometallics, 2010, 29, 6051.

19 M. Kimura and Y. Uozumi, J. Org. Chem., 2007, 72, 707.

20 A. Altomare, M. C. Burla, M. Camalli, G. Cascarano, C. Giacovazzo, A. Guagliardi, A. G. G. Moliterni, G. Polidori and R. Spagna, J. Appl. Crystallogr., 1999, 32, 115-119.

21 L. J. Farrugia, J. Appl. Crystallogr., 1999, 32, 837-838.

22 P. V. D. Sluis and A. L. Spek, Acta Crystallogr., Sect. A: Found. Crystallogr., 1990, 46, 194.

23 A. L. Spek, Acta Cryst., 1990, A 46, C34. 